한국심리학회지: 산업 및 조직

Korean Journal of Industrial and Organizational Psychology

2012. Vol. 25, No. 4, 661-680

\title{
When females are more risk aversive?: Gender and Risk-taking behavior
}

\author{
Dinara Shosaidova \\ Seungwoo Kwon $^{\dagger}$ \\ Jihye Park
}

Korea University Business School

\begin{abstract}
Although the issue of gender differences in risk taking behavior has been an interesting issue of industrial and organizational psychology fields, there is no univocal agreement on this topic. In this paper, we try to find supportive evidence that gender affects risk-taking behavior that is moderated by the frame. In addition, we extend the previous findings by adding variables such as ambition, responsibility, and internal locus of control. As expected, gender and frame interact to influence risk-taking behavior, such that positively framed men are prone to take more risks, whereas negatively framed women prefer risk-taking options. In addition, ambition and the level of internal locus of control are positively related to risk-taking behavior, while responsibility level is negatively related to risk-taking behavior. The implications and limitations of findings are discussed.
\end{abstract}

Key uords : Gender, Risk Taking, Frame, Prospect Theory, Ambition, Responsibility, Internal Locus of Control

† 교신저자 : 권성우, 고려대학교 경영대학, 02-3290-2604, winwin@korea.ac.kr 
The issue of gender differences in risk-taking behavior has been an issue of interest for many scholars of industrial and organizational psychology for past decades. However, there is no univocal point of view on this topic. The aim of this paper is to find supportive evidence that gender affects risk-taking behavior that is moderated by the frame. In addition, we extend previous findings by explaining the process how these two variables interact to influence risktaking behavior. We investigate variables such as ambition, responsibility, and internal locus of control as mediating variables.

According to Byrens, Miler, and Schafer's (1999) meta-analysis, there are gender discrepancies in making general decisions; males prefer risks-taking than females. However, Burens and his colleagues (1990) also suggested that the gender discrepancies of making risky decisions will be diminished by 7 conditions changed: biological maturation, cognitive scope, self-perceptions, perceptions of the social environment, personal values, risk perception, and characteristics of the peer group.

On the other hand, some researchers proved opposite hypothesis that female subjects do not generally make less risky financial choices than male subjects (Schubert, Brown, Gysler, \& Brachinger, 1999). Moreover, Schubert and colleagues (1999) also pointed out that there is a decision frame distinguished; men are more risk-prone toward gains but women are more risk-prone toward losses. Accordingly, previous research concluded that the notion that female investors are more risk-aversive is prejudice rather than fact, even though studies proving female risk-aversion are more numerous and generally supported.

The tendency of males to be more risk-prone towards gain situations and females to be more risk-prone towards loss situations could be explained by the nature of genders. More precisely, by tradition, males used to be main earners for the family, so all daily routines were bounded with risk in gain situations. In contrast, women, who were connected with household, were dealing more with situations where the main goal was how to manage household in a parsimonious way and not to lose goods that they already possessed. Even though the roles of males and females changed a lot in contemporary society, we still think that some of the inherent traits could not change rapidly.

We also claim that there would be the connection among gender, risk-taking behavior, frame and three mediating variables: ambition, responsibility, and internal locus of control. The more ambitious the person is, the more he or she will be willing to take risk.

In contrast, less ambitious people are not confident and prefer rather not to choose risky options. An individual feeling highly responsible for the outcomes are less likely to take risks especially when he or she attributes the failure to himself or herself. In addition, we suppose that people having high level of internal locus of 
control, who tend to perceive themselves as having control over a situation, will be more likely to take risk than people with low level of internal locus of control who think that they avoid decision making and everything is determined by external forces, either fate, circumstances, or other people.

\section{Theoretical Backgrounds}

\section{Risk-Taking Behavior and Gender}

Many studies have investigated the gender differences in risk aversion. Still the views differ greatly among the researchers of industrial and organizational psychology, marketing studies, and organizational behavior fields. Many researchers support the view, that on average, women tend to be more risk averse than men.

In the study of Jianakoplos and Bernasek (1998), they found significant support for the view that women are more risk averse on financial decisions. They also claim that risk aversion is negatively related to household wealth and related to marital status; and race matters. Some of the researchers suppose that women in general are expected to be more conservative investors than men and are consequently offered investments with lower risks and therefore lower expected returns (Bajtelsmit, Bernasek, \& Jianakoplos, 1999; Bajtelsmit \& VanDerhei, 1997; Bernasek \& Swift, 2001; Hinz, McCarthy,
\& Turner, 1997; Sunden \& Surrette, 1998; Wang, 1994). Some experimental evidence suggests that women may be more risk-averse than men towards gambles (Levin, Snyder, \& Chapman, 1988). However, the behavior in abstract gambling experiments may not correspond to risk behavior in contextual decisions (Hershley, \& Schoemaker, 1980).

A recent study by Olivares, Diaz, and Besser (2008) supports previous findings by examining pension funds. They found that women tend to invest in less risky portfolios and hence they tend to get lower funds balances.

Quite the opposite findings are presented in the paper by Iqbal, O, and Baek (2006). They found that female executives do not exhibit more risk aversion than male executives. These findings are consistent with the results of Bliss and Potter (2002) who found that women take more risk than men.

Sapienza, Zingales, and Maestriperi (2009) found significant nonlinear effect of testosterone on risk aversion not only of male participants but also of female participants. The results suggest that higher levels of circulating testosterone were associated with more risktaking behavior among women, but not among men. However, at comparably low concentrations of testosterone the gender difference in risk aversion disappeared. Also they found that individuals with high testosterone were more likely to choose risky careers in finance.

Previous research shows that there is a 
difference in risk perception that can be explained by individual differences (Brockhaus, 1982; Cooper, Woo, \& Dunkelberg, 1988; Mellers, Schwartz, \& Weber, 1997), situational differences, as mentioned above depending on the positive or negative frame (Weber \& Milliman, 1997), or cultural differences (Weber, Hsee, \& Sokolowska, 1998).

\section{Frame}

Frame concepts originated from the prospect theory of Kahneman and Tversky (1979). Prospect theory assumes that decision outcomes can be viewed either as gains or losses from a neutral baseline. In this theory value is assigned to gains and losses. The value function is normally concave for gains (implying risk aversion) and convex for losses (risk seeking) (Fischoff, 1983; Kahneman \& Tversky, 1979, 1984; Tversky \& Kahneman, 1981). The prospect theory describes the process of risky decision making as consisting of two stages: editing and evaluation. First, people tend to set the reference point and then consider whether the outcomes are higher or lower than established reference point. Lower outcomes are considered as losses and higher outcomes are considered to be gains. People are computing the value based on the potential outcomes and their probabilities and then choose the alternative with the higher utility. Peterson and Lawson (1989) examined the effect of prospect theory on politics. They found that the tendency of risk-aversive behavior in the positive frame and risk-seeking in the negative frame has a strong impact on political variables, such as vote intention or political involvement.

In this study we investigate how gender and the frame interact to influence risk-taking behaviors. More specifically, we expect that males would be more risk-taking in the positive frame (gain situation), whereas females would be more risk-taking in the negative frame (loss situation). This difference from our point of view could be explained by the traditional sex-role perception. More specifically, when males used to be the only earners for the whole family, males' daily routines were bounded with risk in gain situations. In contrast, women were occupied in the routines connected with family work in which the main goal was how to manage household in a parsimonious way. Even though the roles of males and females changed a lot in contemporary society, we can suppose that some of the inherent traits have not changed so rapidly.

This paper tries to find supportive evidences and extend the notion presented in the paper of Schubert et al. (1999). The authors claimed that female subjects do not generally make less risky financial choices than male subjects. They show different patterns of risk taking behavior according to the decision frame; men are more risk-prone toward gains but women are more risk-prone toward losses. Based on these 


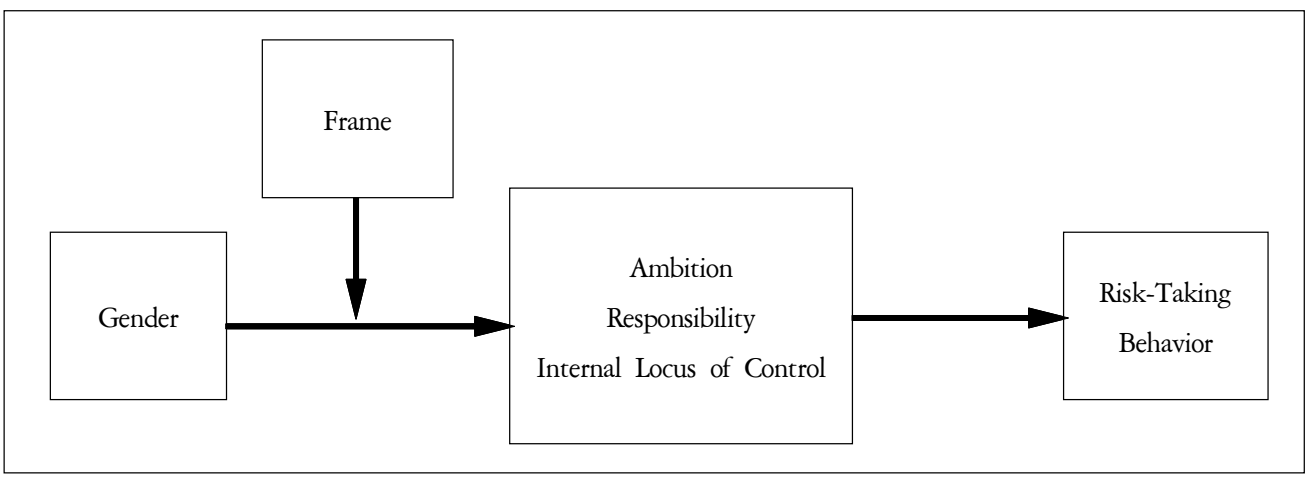

Figure 1. Research Model

arguments, we establish the hypothesis 1.

Hypothesis 1a: In the loss frame, females are more likely to show risk-taking behavior than males.

Hypothesis 1b: In the gain frame, males are more likely to show risk-taking behavior than females.

The current study tries to elaborate the notion that gender affects risk-taking behavior, and this relationship is moderated by the frame (positive and negative). In addition, we extend the previous findings by adding 3 mediating variables: ambition, responsibility, and internal locus of control. We claim that ambition and the level of internal locus of control are positively related to risk-taking behavior, while responsibility level is negatively related to risk-taking behavior. All the hypotheses presented above are described in the following model (Figure 1).

\section{Ambition}

There is a common notion that men are more ambitious than women, especially for politics and business. Still in the recent years with the rise of the percentage of women in government and business positions, the issue that women are less ambitious has been argued. Despite the claim that politics is a men's game, several studies have examined the issue more deeply (Constantini, 1990; Edmunds, 1977). While women are less ambitious than their male counterparts, they revealed that political women play significant role issue clarification and organizational maintenance. (Constantini, 1990; Edmunds, 1977).

One of the explanations for the differences in the level of ambition between women and men lies in the fact that men tend to be up or out, while women have greater staying power that places them into a position to take advantage of the opportunities to run for higher level office (Burt, 1992). 
Despite the wide-spread point of view that men are more ambitious, nowadays we can observe the tendency that women exhibit more male traits and higher ambitions in business. In recent years, a great number of researchers tried to investigate whether there is a difference in ambition level depending on gender (e.g., Constantini, 1990; Edmunds, 1977; Burt, 1992; Turner, 1964). Some of them claim that males due to the masculine nature are more ambitious, while some proved that, in modern society, women are becoming more and more ambitious. Moreover, they argue that there is a tendency that women could beat men in ambitiousness. It has been found that women who value intrinsic rewards highly are more likely to seek careers and are more ambitious than men (Turner, 1964). However, it should be clarified that this tendency is supposed to be observed when the situation is negatively framed. In turn, the higher the ambition level, the more likely it is that the person will exhibit stronger risk-taking pattern.

In this paper we hypothesize that there is a link between gender and ambition whose relationship is moderated by frame. In turn, ambition level is positively related with risktaking behavior. Based on the notions expressed in Hypotheses $1 \mathrm{a}$ and $1 \mathrm{~b}$, we hypothesize that females will be more ambitious than males in the negative frame, while males will be more ambitious than females in the positive frame. Therefore, ambitious people are more risk-prone since they are more confident about their decision makings.

Hypothesis 2a: In the loss frame, women are more ambitious than males.

Hypothesis 2b: In the gain frame, males are more ambitious than females.

Hypothesis 2c: There is a positive relationship between the level of ambition and risk-taking behavior.

\section{Responsibility}

Responsibility issue has a philosophic nature. Based on Fingarette's (1966) review, there are several approaches for studying responsibility. First approach considers moral responsibility hinging upon certain aspects of character and circumstances of action. Second approach is based on the notion that responsibility hinges upon answerability of a person. Finally, combining these two approaches is suggested.

Even though there are several approaches to the notion of responsibility, this paper deals with the concept of responsibility as one of personal characteristics. We try to find links between responsibility, gender, and frame. Based on the Hypotheses $1 \mathrm{a}$ and 1b, we suppose that, in the negative frame, females will be less responsible because they would be more risk-taking and more ambitious. On the other hand, in the positive frame, males are expected to have less responsibility than females. 
Charness (2000) suggests that an agent who bears the responsibility for the outcome will behave in a more "pro-social" manner. We extend this notion by claiming that people who bear responsibility will tend to be risk averse in decision making. We claim that more responsible person will take less risk, because conscious and responsible individual will think about the risky decisions much more thoroughly than a person with lower level of responsibility. Therefore, responsibility level is expected to be negatively related to risk-taking behavior.

Hypothesis 3a: In the loss frame, females are likely to be less responsible than males.

Hypothesis 3b: In the gain frame, males are likely to be less responsible than females.

Hypothesis 3c: There is a negative relationship between responsibility and risk-taking behavior.

\section{Internal Locus of Control}

Rotter (1966) introduced the term of locus of control as the construct of whether the individual perceives that he or she possesses control over the ongoing events (internal locus of control) or considers the ongoing processes as being controlled by external forces (external locus of control). It has been claimed that individuals with internal locus of control tend to exhibit more effort and persistence resulting in higher achievement. In contrast, people with external locus of control tend to see no connection between their behavior and outcomes and thus achieve less outcomes.

There have been studies on the relationship between gender and locus of control. Early research indicates when women achieve success, they are more likely to attribute their success to external factors than men (Simon \& Feather, 1973). Newhouse (1974), however, found no difference between men and women in accepting credit for success. On the other hand, some researchers demonstrated that women are more likely to attribute their failures to internal factors such as lack of ability (Calicchia \& Pardine, 1984; McMahan, 1971; Newhouse, 1974). In sum, it has been found that a man's success is attributed to internal causes, while a woman's success is attributed to external causes (Deaux \& Emswiller, 1974). However, in more recent study, Freedman (1992) examined the relationship between locus of control and gender, and found no significant difference between males and females.

We try to resolve the conflicting results of previous studies on the relationship between gender and locus of control by testing the moderating effect of frame. We assume that in the negative frame females would have higher level of internal locus of control, since they are supposed to be more confident in this situation; and likewise males would have higher level of internal locus of control in the positive frame.

We hypothesize that an individual who has a 
high level of internal locus of control would be more likely to take risk, since internal locus of control refers to the extent that a person perceives himself or herself as possessing control over the event. When an individual believes that he or she has power to control the outcome of an event, he or she would be more likely to make riskier decisions. Therefore, we expect that internal locus of control would be positively related to risk-taking behavior.

In this paper, we claim that internal locus of control is a mediating variable between gender and risk taking. In addition, the relationship between gender and locus of control will be moderated by the frame.

Hypothesis 4a: In the loss frame, females are likely to have a higher rate of internal locus of control than males.

Hypothesis 4b: In the gain frame, males are likely to have a higher rate of internal locus of control than females.

Hypothesis 4c: There is a positive relationship between internal locus of control and risk-taking behavior.

\section{Method}

\section{Sample}

Total sample size is 200 people (Koreans: 58, foreigners: 142). One hundred people were asked to respond to the positively framed questionnaire, and the other 100 people were asked to respond to the negatively framed questionnaire. The proportion of males and females was $50 \%$ and $50 \%$. For each frame, equal number of Koreans and foreigners were asked to respond to the survey questions. People from 24 countries participated in the survey: South Korea, USA, Canada, Denmark, Cameroon, Uzbekistan, China, France, Germany, Kazakhstan, Ukraine, Russia, India, Kenya, Colombia, Mexico, Philippines, Japan, Iran, Kyrgyzstan, Malaysia, Bulgaria, Norway and Zimbabwe. The distributed questionnaire was written in English. It contained two situations (for positive and negative frames) that required making decision whether to take a risk or not to take a risk. Each questionnaire had a part that measured ambition, responsibility and internal locus of control variables adjusted for positive and negative frame situations. Questionnaires were distributed through e-mail or in person. Average age of respondents is 25.9. All respondents had at least bachelor's degree, including master's degree candidates or holders.

\section{Measures}

\section{Ambition}

Ambition was measured using seven-item adapted from Eysenck's Personality Profiler, EPP (Eysenck \& Wilson, 1991). Respondents were asked to rate the items on a seven-point Likert 
scale $(1=$ not at all, $7=$ completely $)$. Items 2 and 5 were re-coded while processing the data due to reverse phrasing. Reliability coefficient $a$ was .88 .

These items are as follows: "Do you desire to be an important person in your organization?", "Do you set your aspirations low in order to avoid disappointments?", "Would you compare your ability and time needed to execute the construction project with that of your colleagues?", "Would you get excited when you are telling someone about your future plans to build sport complexes? / Would you get excited when you are telling someone about your plans of fixing the malfunction at your company?" (For positive and for negative frames respectively), "Are you satisfied with the things just as they are rather than striving to improve your performance when you make a decision?", "Do you prefer to mix with people who are ambitious and successful?", "Do you think it is important to make a creative contribution when you make a decision?"

\section{Responsibility}

We measured responsibility using three-items that are adopted from on-line psychological web-sites. Respondents were asked to rate the items on a seven-point Likert scale $(1=$ not at all, $7=$ completely). Reliability coefficient $a$ was .87. The items are as follows (for positive and for negative frames respectively): "P: You know that your competitors cannot set all the objects on time, so the general deadline will be postponed. Will you still work on completing all the objects on time set in the contracts? / $\mathrm{N}$ : Do you try to fix the malfunction immediately instead of putting it off until later?", "P: Will you still obey the whole set of demands of the ordering party, knowing that some of the competitors satisfy only the part of them? / $\mathrm{N}$ : Do you think that no matter how hard it would be the work should be done properly?", "P: You are suddenly offered a better contract from a third party, but you already signed the contract. Will you keep your promise no matter how inconvenient it might turn out to be? / N: If you said that you would fix the problem, will you keep your promise no matter how inconvenient it might turn out to be?"

\section{Locus of Control}

Internal locus of control was also measured using three-items that are modified from Rotter (1966). Respondents were asked to rate the items on a seven-point Likert scale $(1=$ not at all, $7=$ completely). Reliability coefficient $a$ was .82 .

The specific items are as follows: "Even though boss told you to fix the problem you still can delegate this problem to your subordinate. Are you still likely to control everything by yourself?", "When you make a decision to choose either of two variants concerning construction of sport complexes, are you sure that your plan will work?", "In this 
situation, do you believe that the outcome depends only on your hard work, persistence and ability?"

\section{Results}

Validity

Validity test proved that all the items measuring the variable are appropriate for the analysis, for all items were higher than .50 . Results are significant at .01 level and high Eigenvalues represent meaningfulness of factors. High overall Kaiser-Meyer-Olkin value (>.60)

Table 1. Factor Analysis

\begin{tabular}{cccc}
\hline & \multicolumn{3}{c}{ Factor } \\
\cline { 2 - 4 } Amb1 & 1 & 2 & 3 \\
\hline Amb2 & .84 & .34 & .24 \\
Amb3 & .71 & -.49 & .35 \\
Amb4 & .71 & -.37 & .41 \\
Amb5 & .61 & -.47 & .41 \\
Amb6 & .81 & .39 & .42 \\
Amb7 & .73 & .41 & -.28 \\
Resp1 & -.56 & .50 & .39 \\
Resp2 & -.61 & .68 & .42 \\
Resp3 & -.63 & .54 & -.32 \\
Contr1 & -.20 & .26 & .78 \\
Contr2 & -.19 & .30 & .84 \\
Contr3 & -.21 & .46 & .70 \\
\hline$N=200$ & & &
\end{tabular}

$N=200$ proves that correlation matrix is suitable for factor analysis. Extraction method used for the factor analysis was principal axis factoring, though no items were excluded due to the values higher than 50. Three Eigenvalues are higher than 1 , therefore three factors are extracted.

Form the structure matrix we can observe that components from Amb1 through Amb7 are highly loaded on Factor 1, components from Resp2 through Resp3 are highly loaded on Factor 2, and components from Contr1 to Contr3 are highly loaded on Factor 3. Thus, we put 13 variables into 3 factors: ambition, responsibility, and locus of control. Extraction method used for validity check was Principal Axis Factoring with Promax Kaiser Normalization.

\section{Correlation Analysis}

Correlations between variables are significant at .001 and .01 levels (two-tailed). There is a strong positive correlation between ambition and risk-taking behavior $(r=.67, p<.001)$, which supports the part of the hypothesis that ambitious people tend to be more risk-taking. The correlation between responsibility and risk-taking behavior is significant and negative $(r$ $=-.71, p<.001$ ), which proves the hypothesis that more responsible people are less risk-taking. Internal locus of control is positively correlated with risk taking $(r=.59, p<.001)$. This 
Table 2. Descriptive Statistics and Correlation

\begin{tabular}{lccccccccc}
\hline \multicolumn{1}{c}{ Variables } & $M$ & $S D$ & 1 & 2 & 3 & 4 & 5 & 6 & 7 \\
\hline 1. Gender & 1.51 & .50 & & & & & & \\
2. Native/Foreigner & 1.50 & .50 & .01 & & & & & & \\
3. Risk-taking & 1.40 & .49 & .05 & .02 & & & & \\
4. Age & 25.98 & 4.32 & -.07 & -.17 & -.03 & & & & \\
5. Frame & 1.50 & .50 & -.01 & .00 & .10 &.$(a)$ & & \\
6. Ambition & 4.97 & 1.30 & .03 & -.01 & $.67^{* * *}$ & .06 & .13 & \\
7. Responsibility & 5.18 & 1.27 & -.04 & .04 & $-.71^{* * *}$ & .04 & -.03 & $-.57^{* * *}$ & \\
8. Control & 4.47 & 1.58 & .01 & .01 & $.59^{* * *}$ & .09 & $.23^{* *}$ & $.78^{* * *}$ & $-.51^{* * *}$ \\
\hline$N=200,{ }^{*} p<.05,{ }^{* *} p<.01,{ }^{* * *} p<.001$ & & & & & &
\end{tabular}

(a) Cannot be computed because at least one of the variables is constant.

result proves the hypothesis that people who believe that they have control over the events are more likely to take risks. We also found positive correlations between the frame and internal locus of control $(r=.23, p<.01)$. We observed negative correlations between ambition and responsibility $(r=-.57, p<$ $.001)$ : and responsibility and control $(r=-.51$, $p<.001)$. We also found the positive relationship between ambition and internal locus of control $(r=.78, p<.001)$.

\section{Hypothesis Testing}

Due to the nature of variables to test the relationship between gender and risk-taking behavior in different frames (Hypotheses 1a, 1b), non-parametric binomial test was used. As table

Table 3. Binomial Test Results for Negative and Positive Frame

\begin{tabular}{|c|c|c|c|c|c|c|}
\hline & & $N$ & $\begin{array}{l}\text { Observed } \\
\text { Proportion }\end{array}$ & $\begin{array}{c}\text { Test } \\
\text { Proportion }\end{array}$ & $\begin{array}{l}\text { Asymptotic } \\
\text { Significance } \\
\text { (2-tailed) }\end{array}$ & $\begin{array}{c}\text { Exact } \\
\text { Significance } \\
\text { (2-tailed) }\end{array}$ \\
\hline \multirow{3}{*}{$\begin{array}{c}\text { Negative } \\
\text { Frame }\end{array}$} & Males & 13 & .29 & .50 & $.007(a)$ & $.007(\mathrm{~b})$ \\
\hline & Females & 32 & .71 & & & \\
\hline & Total & 45 & 1.00 & & & \\
\hline \multirow{3}{*}{$\begin{array}{l}\text { Positive } \\
\text { Frame }\end{array}$} & Males & 24 & .69 & .50 & $.041(a)$ & $.041(b)$ \\
\hline & Females & 11 & .31 & & & \\
\hline & Total & 35 & 1.00 & & & \\
\hline
\end{tabular}


3 shows, binomial test allows us to test whether the proportion of females/males on a two-level categorical dependent variable (risk-taking) significantly differs from a hypothesized value. From all the samples of positive and negative frame (separately), we excluded the responses that people chose risk-aversive alternative. Among the sample of risk-takers, proportions have been calculated using binomial test. In the positive frame we hypothesize that the proportion of males would be less or equal to 50. The obtained result indicates that there is marginally significant statistical difference $(\phi<$ .10). The same scheme was applied to test the proportion of male risk-takers in the negative frame $(p<.05)$. The results were different from the hypothesized values. Hence, the proportion of females in the negative frame is higher than the proportion of males, and vice versa; the proportion of males in the positive frame is higher than the proportion of females.

Two-way ANOVA was used to test if there is a relationship between gender and mediating variables (ambition, responsibility and internal locus of control), moderated by the frame (Hypotheses 2, 3, 4). From unning the two-way ANOVA for Ambition variable, we found no significant result for both main effects (frame: $p$ $<.08$; gender: $p<.57$ ), but the interaction of these two variables is significant $(p<.01)$. Although the effect size is relatively small $\left(n^{2}\right.$ $=.12)$, this is the most interesting and informative part of this ANOVA test. because it indicates gender difference. Comparing the means for males and females (see Table 4), we can observe that males are more ambitious in the positive frame (males $M=5.21$; females $M=$ 4.41) and females are more ambitious in the negative frame (females $M=5.62$; males $M=$ 4.62). High $F$-value also proves this statement, $F(1,195)=26.97(p<.01)$. These results support Hypothesis 2a and 2b (see Figure 2).

By running the same test for responsibility

Table 4. The Results of ANOVA for Ambition

\begin{tabular}{lcccc}
\hline \multicolumn{1}{c}{ Source } & $d f$ & $F$ & $\begin{array}{c}\text { partial- } \\
\eta^{2}\end{array}$ & $p$ \\
\hline \multicolumn{2}{l}{ Between-Subject Effects } & & & \\
Frame & 1 & 3.23 & .02 & .07 \\
Gender & 1 & .33 & .00 & .57 \\
Frame * Gender & 1 & $26.97^{* *}$ & .12 & .00 \\
Error & 196 & $(1.494)$ & & \\
\hline
\end{tabular}

$N=200$, The number in parenthesis means MSE (Mean Squared Error). Adjust $R^{2}=.12$

$* p<.05, * * p<.01$

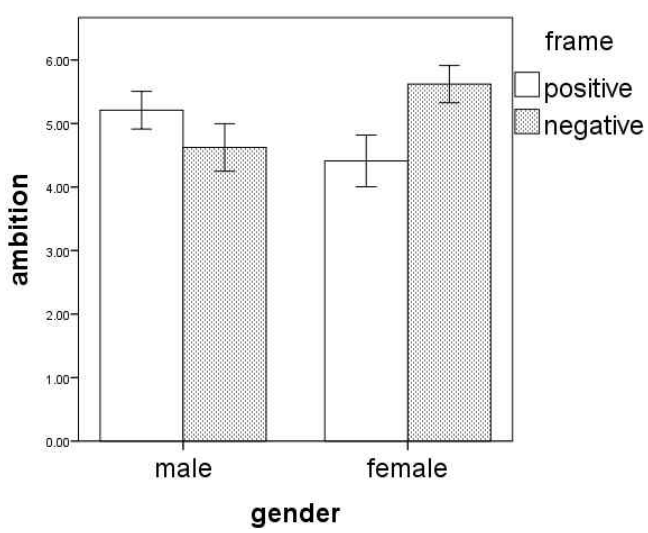

Figure 2. Gender and Frame on Ambition 
variable, similar result has been obtained (see Table 5); no significant result for both main effects (frame $p<.80$; gender $p<.60$ ), but the interaction of these two variables is significant $(p<.01)$. Again, the effect size is relatively small (partial $\eta^{2}=.13$ ). Comparing the means for males and females we can observe than males are more responsible than females in

Table 5. The Results of ANOVA for Responsibility

\begin{tabular}{lrrrr}
\hline \multicolumn{1}{c}{ Source } & df & $F$ & $\begin{array}{c}\text { partial- } \\
\eta^{2}\end{array}$ & $p$ \\
\hline \multicolumn{2}{l}{ Between-Subject Effects } & & & \\
Frame & 1 & .12 & .00 & .73 \\
Gender & 1 & .29 & .00 & .59 \\
Frame * Gender & 1 & $28.70^{* *}$ & .13 & .00 \\
Error & 196 & $(1.419)$ & & \\
\hline
\end{tabular}

$N=200$, The number in parenthesis means MSE (Mean Squared Error). Adjust $R^{2}=.12$

$* p<.05, * * p<.01$

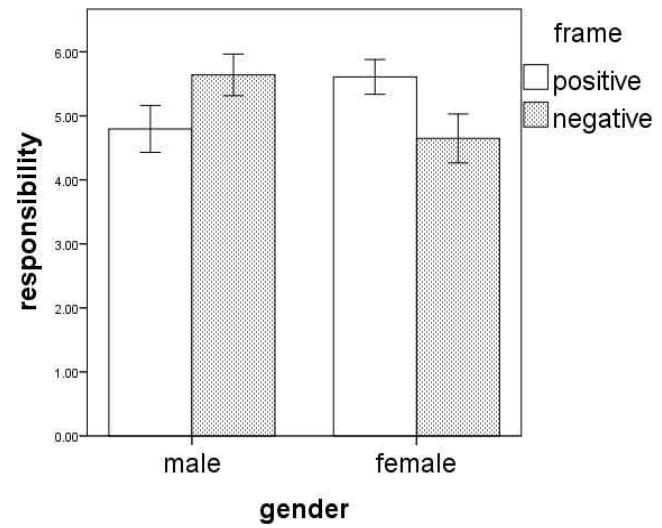

Figure 3. Gender and Frame on Responsibility the negative frame (males $M=5.64$; females $M=4.65)$ and females are more responsible in the positive frame (females $M=5.61$; males $M$ $=4.80)$. High $F$ value also proves this statement, $F(1,196)=28.70, p<.01$. These results support Hypothesis $3 \mathrm{a}$ and $3 \mathrm{~b}$ (see Figure 3).

The results for internal locus of control are as

Table 6. The Results of ANOVA for Locus of Control

\begin{tabular}{lrccc}
\hline Source & $d f$ & $F$ & $\begin{array}{c}\text { partial- } \\
\eta^{2}\end{array}$ & $p$ \\
\hline Between-Subject Effects & & & & \\
Frame & 1 & $12.34^{* *}$ & .06 & .00 \\
Gender & 1 & .02 & .00 & .89 \\
Frame * Gender & 1 & $32.70^{* *}$ & .14 & .00 \\
Error & 196 & $(2.053)$ & & \\
\hline$N=200$, The number in parenthesis & means & MSE
\end{tabular}

(Mean Squared Error). Adjust $R^{2}=.18$

$* p<.05, * * p<.01$

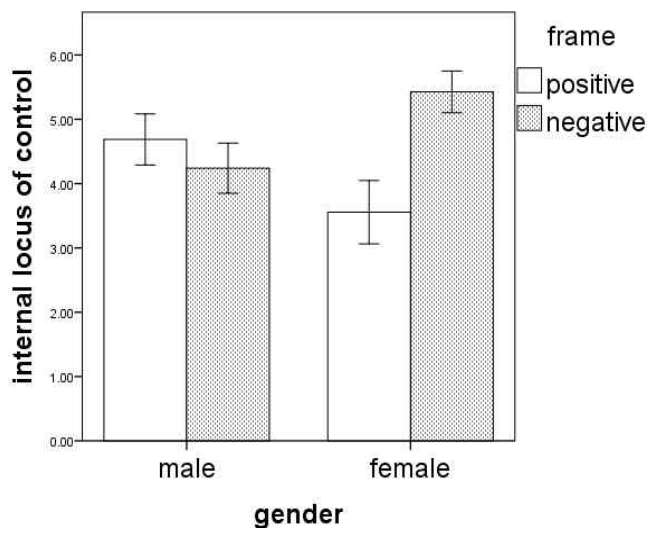

Figure 4. Gender and Frame onlnternal Locus of Control 
Table 7. Classification Results ${ }^{(a)}$

\begin{tabular}{cccccc}
\hline & & & \multicolumn{2}{c}{ Predicted Group Membership } & \multirow{2}{*}{ Total } \\
\cline { 3 - 4 } & & & Risk-avoidance & Risk-taking & \\
\hline \multirow{3}{*}{ Original } & \multirow{2}{*}{ Count } & Risk-avoidance & 108 & 11 & 119 \\
& & Risk-taking & 12 & 68 & 80 \\
\cline { 3 - 5 } & & Risk-avoidance & 90.8 & 9.2 & 100.0 \\
& & Risk-taking & 15.0 & 85.0 & 100.0 \\
\hline
\end{tabular}

(a) $88.4 \%$ of original grouped cases correctly classified.

follows (see Table 6); there is also no significant result for gender $(p<.90)$, but the interaction of gender and the frame is significant $(p<$ $.01)$. The effect size is also relatively small (partial $\eta^{2}=.14$ ), but indicating gender difference. Comparing the means for males and females, we can observe that males have higher levels of internal locus of control than females in the positive frame (males $M=4.69$, females $M$ $=3.56$ ) and females have higher rate of internal locus of control in the negative frame (females $M=5.43$, males $M=4.24$ ). High $F$ value also proves this statement, $F(1,196)=$ $32.71,(\phi<.01)$. These results support Hypothesis $4 \mathrm{a}$ and $4 \mathrm{~b}$ (see Figure 4).

Discriminant analysis was used to test the relationship between 3 mediators (ambition, responsibility, and internal locus of control) and risk-taking behavior (Hypotheses 2c, 3c, 4c), since independent variables are continuous and the dependent variable is categorical. Comparing the values, we can conclude that the relationship between ambition, responsibility, and control are significant $(\phi<.05$ respectively). Comparing the means for two data sets - risk-taking and risk-avoidance, we observe that the ambition and locus of control engender higher values in the risk-taking, while the responsibility causes higher values in the risk-avoidance. Overall, the results show that $88.4 \%$ of originally grouped cases were correctly classified. $90.8 \%$ of cases are accurately classified for risk-avoidance pattern separately and $85.0 \%$ for risk-taking cases. Wilk's lambda $(\lambda=.39, p<.001)$ shows that each function is significant. In addition, high Eigenvalue (eigenvalue $=1.56$, canonical correlation $=.78$ ) means that the difference in the dependent variable is explained by this function. Therefore, hypotheses $2 c, 3 c$, and $4 c$ are supported.

\section{Discussion}

\section{Summary and Conclusions}

In this study we examined the gender difference in risk-taking behavior, which is 
moderated by the frame and mediated by three variables: ambition, responsibility and internal locus of control. It has been hypothesized that females would be more ambitious, less responsible, and have higher level of internal locus of control in the loss frame (a negative situation), resulting in more risk-taking behavior. In addition, males would be more ambitious, less responsible, and have higher level of internal locus of control in the gain frame (a positive situation), consequently more risk taking behavior.

Many studies have been conducted on the topic 'Gender and Risk,' but still scholars cannot agree on one point of view. Most of the researchers tend to think that on average females are more risk aversive than males (Jianakoplos \& Bernasek, 1994, 1998; Olivares et al., 2008). There are other studies that linked risk-taking behavior, gender and wealth of respondents (Halek, 2001) and even the level of testosterone (Sapienza et al., 2009).

By adding three mediation variables ambition, responsibility, and internal locus of control, we tried to find support and extend the previous findings of Schubert et al. (1999) that proved that gender influences risk-taking behavior whose relationship is moderated by the frame.

First, this paper predicted that gender influences risk-taking behavior, moderated by the frame. By testing this hypothesis using non-parametric binomial test, we proved that in the loss frame females are more risk-taking than males, and in the gain frame males are more risk-taking than the females. Females tend to be more aggressive when it goes about losses and males when it goes about gains. According to Higgins' (2002) regulatory focus theory, men are more prone to take risks in gain frame because they have promotion focus, while women are more likely to take risks in loss frame due to their prevention focus.

We confirmed the argument of Schubert et al. (1999) in that females are more ambitious than males in the loss frame, while males are more ambitious than females in the gain frame. In addition, we found that, in the loss frame, females are less responsible and have higher internal locus of control than males; but in the gain frame, males are less responsible and have higher internal locus of control than females.

Our study revealed the process how gender influences risk-taking behavior by investigating 3 mediators: ambition, internal locus of control, and responsibility. Ambition and internal locus of control are positively related to risk-taking behavior, and responsibility has negative relationship with risk-taking behavior.

Supplemental analyses revealed some interesting results. For example, in the negative frame when people are concerned about losses, people tend to attribute their achievements and failures to themselves, while in the positive frame when it goes about gains, people tend to attribute their achievements and failures to 
external factors. Also we found that ambitious people are less responsible, but have higher degrees of internal locus of control; and responsible people tend to have lower level of internal locus of control.

In summary, we found strong relationship between gender and risk-taking behavior, which is moderated by positive and negative frame. In addition, we found 3 mediting varibles (ambition, risk-taking behavior, and internal locus of control).

\section{Practical Implications}

Our findings suggest that men and women tend to show different patterns in risk taking behavior. Based on these findings, organizational managers need to develop human resource management strategies accordingly. First, if an organizational manager wants to promote a focal behavior, he or she can use gain-framed HR practices (providing a positive situation) for men, then they will be more ambitious, less responsible, and have more locus of control, and finally they will be willing to behave the expected behaviors. In the case of women, a manager can use this in an opposite way. This suggestion is consistent with $\mathrm{He}$, Inman, and Mittal (2008). They (2008) revealed interaction effect between frame (gain vs. loss) and gender (male vs. female) using different decision tasks (e.g., investment decisions and insurance decisions).
Second, if a manager wants employees to make risky decisions to follow organization's policies, he or she needs to consider not only how to make proper frames but also how to increase ambition level, lower responsibility, or prompt their internal locus of control level effectively, because these factors play the role of mediators between gender and risk-taking behaviors.

\section{Limitations and Future Research}

This study has some limitations. First of all, while distributing the questionnaire, the manipulation check was not provided. Manipulation check could have helped to reveal whether the experiment produced the desired psychological state more clearly. In the distributed questionnaires, however, the situation describing financial loss and the exact amount of money was mentioned; in addition, in the gain situation the exact amount of financial gain was mentioned.

Therefore, the manipulations of gain and loss frame were hardly understood twofold.

Future research might focus on the differences in gender regarding social status and background. In addition, cultural difference can interact with gender to influence risk-taking behavior. Difference in cultures, legislative systems, and the level of wealth in the country might affect people's decisions to take or not to take risk. 


\section{References}

Bliss, R., \& Potter, M. (2002). Mutual fund managers: Does gender matter? Joumal of Business and Economic Studies, 8, 1-15.

Bajtelsmit, V. L., \& VanDerhei, J. A. (1997). 'Risk aversion and retirement income adequacy', in M. S. Gordon, O. S. Mitchel, \& M. M. Twinney (Eds.), Positioning Pensions for the Twenty-first Century, University of Pennsylvania, Philadelphia: 45-66.

Bajtelsmit, V. L., Bernasek, A., \& Jianakoplos, N. A. (1999). Gender differences in defined contribution pension decisions. Financial Services Review, 8, 1-10.

Bernasek, A., \& Swift, S. (2001). Gender, risk, and retirement. Journal of Economic Issues, 35, 345-356.

Brockhaus, R. H. (1982). The psychology of the entrepreneur. in C. A. Kent, D. L. Sexton, \& K. H. Vesper (Eds.), Encyclopedia of entrepreneurship Englewood Cliffs, Prentice Hall, NJ: pp. 39-71.

Burt, B. J. (1992). Gender and sustaining of political ambition: A study of Arizoma elected officials. Political Research Quarterly, 45(1), 11-25.

Byrnes, J. P., Miller, D. C., \& Schafer, W. D (1999). Gender differences in risk taking: A meta-analysis, Psychological Bulletin, 125(3), 367-383.

Calicchia, J. P., \& Pardine, P. (1984). Attributional style: Degree of expression, respondents' sex, and nature of the attributional event. The Journal of Psychology, 177, 167-175.
Charness, G. (2000). Responsibility and effort in an experimental labor market. Journal of Economic Behavior and Organization, 42, 375- 384.

Constantini, E. (1990). Political women and political ambition: Closing the gender gap. American Journal of Political Science, 34, 741770.

Cooper, A. C., Woo, C. Y., \& Dunkelberg, W. C. (1988). Entrepreneurs' perceived chances for success. Journal of Business Venturing, 3, 97-108.

Deaux, K., \& Emswiller, T. (1974). Explanations of successful performance on sex-linked tasks: what is skill for the male and luck for the female. Joumal of Personality of Social Psychology, 29(1), 80-85.

Edmunds, S. W. (1977). Unifying concepts of social responsibility. The Academy of Management Review, 2(1), 38-45.

Eysenck, H. J., \& Wilson, G. D. (1991). The Eysenck Personlaity Profiler. Cymeon, Brisbane, Australia. (Specific Questionnaire available at http://breakout2.org/down/KNOW\%20 YOUR\%20OWN\%20MIND\%20Personality\%2 0Questionnaire.pdf)

Fingarette, H. (1966). Responsibility. Mind, New Series, pp. 58-74

Fischoff, B. (1983). Predicting Frames. Joumal of Experimental Psychology: Learning, Memory and Cognition, 9, 103-116.

Freedman, S. A. (1992). Sex, gender, and locus of control in college students. Paper presented at the Annual Convention of the American Psychological Association. (100th, Washington D.C., August 14-18, 1992). 
Halek, M. \& Eisenhauer, J. G. (2001). Demography of risk aversion. The Journal of Risk and Insurance, 68(1), 1-24.

He, X., Inman, J., \& Mittal, V. (2008). "Gender jeopardy in financial risk taking," Journal of Marketing Research, 45, 414-424.

Hershley, J., \& Schoemaker, P. (1980). Risk taking and problem context in the domain of losses: An expected utility ananlysis. Joumal of Risk and Insurance, 47(1), 111-132.

Hinz, R. P., McCathy, D. D., \& Turner, J. A (1997). 'Are women conservative investors? Gender differences in participant-directed pension investments'. in Mitchell, O. (Ed.) Positioning Pensions for the Year 2000, University of Pennsylvania Press, Philadelphia: pp. $91-103$

Iqbal, Z., O, S., \& Baek, H. Y. (2006). Are female executives more risk-averse than male executives? Atlantic Economic Joumal, 34, 6374.

Jinakoplos, N. A., \& Bernasek, A. (1998). Are women more risk averse? Economic Inquiry, 36, 620-630.

Jinakoplos, N. A., \& Bernasek, A. (1994). Decision making, risk and gender: Are managers different? British Joumal of Management. 5(2), 123-138.

Kahneman, D., \& Tversky, A. (1979). Prospect theory: An analysis of decision under risk. Econometrica, 43(2), 263-292.

Kahneman, D., \& Tversky, A. (1984). Choices, values, and frames. American Psychologist, 39(4), 341-350.

Levin, I., Snyder, M. A., \& Chapman, D. P.
(1988). The interaction of experiential and situational factors and gender in a simulated risky decision-making task. Journal of Psychology, 122(2), 173-181.

Mellers, B. A., Schwartz, A., \& Weber, E. U. (1997). Do risk attitudes reflect in the eye of the beholder? Choice, Decision and Measurement: Essays in Honor of R. Duncan Luce, 59-73.

Newhouse, R. C. (1974). Reinforcement -responsibility differences in birth order, grade level and of sex children in grades four, five and six. Psychological Reports, 34, 699-705.

Olivares, J. A., Diaz, D., \& Besser, M. (2008). Gender and portfolio choice: Are women more risk averse when selecting pension funds? Research Draft. 1-13. Journal of Economic Literature-Classification number: J16, G11, G23.

Peterson, S., \& Lawson, R. (1989). Risky Business: Prospect theory and politics. Political Psychology, 10(2), 325-339.

Rotter, J. B. (1966). Generalized expectancies for internal versus external control of reinforcement. Psychological Monographs, 609, 80.

Rotter, J. B. (1975). Some problems and misconceptions related to the construct of internal versus external control of reinforcement. Journal of Consulting and Clinical Psychology, 43(1), 56-67.

Sapienza, P., Zingales, L., \& Maestripieri, D. (2009). Gender differences in financial risk aversion and career choices are affected by testosterone. National Academy of Sciences, 106(36), 15268-15273. 
Schubert, R., Brown, M., Gysler, M., \& Brachinger, H. W. (1999). Financial decision making: Are women really more risk-averse? The American Economic Review, 89(2), 338- 385.

Simon, J., \& Feather, N. (1973). Causal attributions for success and failure at university examinations. Journal of Educational Psychology, 64, 45-56.

Sunden, A. E. \& Surette, B. J. (1998). Gender differences in the allocation of assets in retirement savings plans. The American Economic Review, 88(2), 207-211.

Turner, R. (1964). The social context of ambition: The study of high-school seniors on Los Angeles. San Francisco: Chandler Publications in Anthropology and Sociology.

Tversky, A., \& Kahneman, D. (1981). The framing of decisions and the psychology of choice. Journal of Experimental Psychology: Learning, Memory and Cognition, 211, 453-458.
Wang, P. (1994). Brokers still treat men better than women. Money, 23(6), 108-110.

Weber, E. U., \& Hsee, C. (1998). Cross-cultural differences in risk-perception, but cross cultural similarities in attitudes towards perceived risk. Management Science, 44(9), 1205-1217.

Weber, E. U., Hsee, C., \& Sokolowska, J. (1998). What folklore tells us about risk and risk taking: A comparisons of American, German, and Chinese proverbs. Organizational Behavior and Himan Decision Processes, 75(2), 170-186.

Weber, E. U., \& Milliman, R. (1997). Perceived risk attitudes: relating risk perception to risky choice. Management Science, 43, 122-143.

1차 원고접수 : 2012. 9. 10 수정원고접수 : 2012. 11. 12 최종게재결정 : 2012. 11. 19 


\title{
여성들은 언제 더 위험 회피적일까?: 성별에 따른 위험 감수 행동의 차이 연구
}

\author{
디나라 쇼사이도바
}

권 성 우

박 지 혜

고려대학교 경영대학

\begin{abstract}
위험 감수 행동에 있어 성에 따른 차이의 문제는 오래 전부터 산업 및 조직 심리학 분야의 관심을 받아왔다. 그러나 본 주제에 대하여 단일한 결론을 도출한 것은 아니다. 따라서 본 연구에서는 성별에 따라 각기 다른 프레임(손실, 이익) 하에서 위험 감수 행동이 다르게 나 타나고, 그러한 차이가 나타나게 되는 기저의 메커니즘으로서 야망, 책임감, 내적 통제력의 매개효과를 확인하고자 하였다. 예상한 바대로, 특정 프레임 하에서 특정 성이 더 위험한 결 정을 하는 것으로 나타났다. 예를 들어 긍정적으로 프레임 된(이익 프레임) 남성은 긍정적 프레임 하의 여성보다 더 위험한 결정을 선택하였고, 반면 부정적으로 프레임 되는 경우(손 실 프레임), 여성이 남성보다 손실 상황에서 더 위험한 결정을 선호하는 것으로 나타났다. 더불어 이익 프레임 하에서 남성은 야망과 내적 통제력이 높아지고, 책임감이 낮아져서 더 위험한 선택을 하고, 손실 프레임 하에서 여성 역시 야망과 내적 통제력이 높고, 책임감이 낮아짐에 따라 더욱 위험한 선택을 한다는 것을 확인할 수 있었다. 즉, 야망과 내적 통제력, 책임감은 특정 프레임 하에서 나타나는 성별과 위험 감수 행동의 관계를 매개하였다. 마지 막으로 본 연구의 시사점 및 한계점에 대하여 논의하였다.
\end{abstract}

주요어 : 성(性), 위험 감수 행동, 프레임, 전망이론, 야망, 책임감, 내적 통제 